sented less than $1 \%$ of total sales of sympathomimetic aerosols. Although this suggests that overuse of nebulisers is unlikely to be a major factor contributing to the current epidemic, the pattern of use may be more important than the total sales, but this cannot be examined in the present study.

One factor that may account in part for the difference in sales of drugs between the countries examined is the cost of prescriptions to the patient. In New Zealand the most frequently prescribed drugs used to treat asthma are free to the patient, whereas the charges for prescriptions in Australia and the UK may act as a financial disincentive. Furthermore, in New Zealand the cost of consultations with general practitioners may discourage patients from seeking the optimum supervision, whereas in the UK there is no financial barrier to consultations with general practitioners. The trends in sales of drugs to treat asthma shown here may reflect international differences in prescribing patterns for all drugs. Indeed, international comparisons of use of drugs per head of population have shown more than twofold differences between countries. ${ }^{14}$

In the absence of comparable data on trends in prevalence and severity of asthma in the countries investigated, the interpretation of our data can only be speculative. Nevertheless, the results of this study show that a dramatic increase in per caput sales of drugs to treat asthma has not been associated with a reduction in mortality due to asthma.
We thank Mr G M Hashimoto of Intercontinental Medical Statistics (NZ) Ltd for providing the information on sales of drugs. RJ acknowledges the support of the Medical Research Council of New Zealand.

\section{References}

${ }^{1}$ Jackson RT, Beaglehole R, Rea HH, Sutherland DC. Mortality from asthma:

a new epidemic in New Zealand. Br Med $\mathcal{J} 1982 ; 285: 771-4$. of asthma in New Zealand. NZ Med F 1983;96:727-9.

of asthma in New Zealand. NZ Med f $1983 ; 96: 727-9$.
Speizer FE, Doll R, Heaf P. Observations on recent increases in mortality from asthma. Br Med $\mathcal{f} 1968 ; \mathrm{i}: 335-9$.

- Inman WHW, Adelstein AM. Rise and fall of asthma mortality in England and Wales in relation to use of pressurised aerosols. Lancet $1969 ; \mathrm{ii}: 279-85$.

Stolley PD, Schinnar R. Association between asthma mortality and isoproterenol aerosols: a review. Prev Med 1978;7:319-38.

' Department of Health and Social Security. Trends in morbidity 1968-1978. Hospital In-patient Enquiry. London: HMSO, 1981.

Mitchell EA. Increasing prevalence of asthma in children. NZ Med $\mathcal{F} 1983$;96: 463-4

${ }^{8}$ Smith JM, Harding LK, Comming S. The changing prevalence of asthma in school children. Clin Allergy 1971;1:57-61.

(1978-80. Part I. Uppsala: Nordiska läkemedelsnämnden, 1982 (NLN Publication No 8.) bined with oral theophylline increased cases of fatal asthma ? Lancet 1981 ; i:12357 .

"Cochrane SM, Clark TJH. A survey of asthma mortality in patients between ages 35 and 65 in the greater London hospitals in 1971. Thorax 1975;30:300-5.

${ }^{2}$ British Thoracic Association. Death from asthma in two regions in England. $\mathrm{Br}$ Med F 1982;285:1251-5.

${ }^{3}$ Grant IWB. Asthma in New Zealand. Br Med f 1983;286:374-7.

4 Macukanovic P, Rabin DL, Mabry JH, Simic D. Use of medicines. In: Kohn R, White KL, eds. Health care: an international study. London: Oxford University
Press, 1976:223-77.

(Accepted 17 May 1984)

\title{
Diazepam tolerance: effect of age, regular sedation, and alcohol
}

\author{
P J COOK, R FLANAGAN, I M JAMES
}

\begin{abstract}
The dose of intravenous diazepam required for sedation was estimated in a series of 78 patients aged 17-85 years given the drug for dental and endoscopic procedures. Multiple regression analysis showed a significant correlation $(\mathbf{r}=0.71 ; p<0.001)$ between dose and age, body weight, the taking of regular sedation, and the taking of more than $40 \mathrm{~g}$ alcohol daily, but there were no differences in the doses required between men and women, smokers and non-smokers, inpatients and outpatients, or dental and endoscopy patients. Patients aged 80 required an average dose of $10 \mathrm{mg}$ and patients aged 20 an average dose of $30 \mathrm{mg}$, and the dose required was much higher in those receiving regular sedation or having a high alcohol intake.
\end{abstract}

Plasma total and free diazepam concentrations were measured in the second half of the series of patients

\footnotetext{
Section of Clinical Pharmacology, Medical Unit, Royal Free Hospital, London NW3

P J COOK, MD, MRCP, honorary senior registrar

I M JAMES, PHD, FRCP, senior lecturer

Poisons Unit, Guy's Hospital, London SE1 9RT

R FLANAGAN, PHD, senior biochemist

Correspondence to: Dr P J Cook.
}

$(\mathbf{n}=37)$. Plasma concentrations required for sedation fell twofold to threefold between the ages of 20 and 80 and were significantly higher in those taking regular sedation or alcohol. Differences in the acute response to diazepam appeared to be due to differences in the sensitivity of the central nervous system (pharmacodynamic tolerance) rather than to differences in pharmacokinetic factors.

\section{Introduction}

The doses of diazepam needed to produce the same degree of sedation varies widely among patients. There is little information about the factors which alter diazepam tolerance and which might be used to predict the dose required. The neurological response to diazepam has been reported to increase with age, ${ }^{12}$ but those results may have been influenced by the selection and distribution of patients, ${ }^{1}$ and the use of additional premedications. ${ }^{2}$ There is also evidence that patients who take the drug regularly, cigarette smokers, ${ }^{3}$ and those who take large amounts of alcohol regularly, ${ }^{4}$ may be more tolerant of its effects.

Diazepam is highly bound to plasma proteins and only the unbound fraction is available for distribution in the tissues. Plasma binding decreases with age ${ }^{5-7}$ and it has been suggested that the rise in free drug concentration will lead to an increase in the clinical response. ${ }^{7}$ We have studied the relation between the dose of diazepam required for sedation and the factors that have been reported to alter the clinical response. The degree total and free diazepam concentrations were also measured to assess the extent to which the clinical response is determined by pharmacokinetic factors. 


\section{Methods}

We studied 78 patients ( 43 men, 35 women) who required diazepam for elective dental and endoscopic procedures. A detailed history of cigarette smoking, alcohol consumption, and medication, was taken. Patients with a history of uraemia (blood urea concentration $>13 \mathrm{mmol} / \mathrm{l},>78 \mathrm{mg} / 100 \mathrm{ml}$ ), hypoalbuminaemia (albumin concentration $<3.5 \mathrm{~g} / \mathrm{l}$ ), multiple drug treatment (more than two drugs a day, excluding antacids), and those taking any type of sedative drug irregularly were excluded. The fasting patients were given a slow intravenous injection of diazepam $(3 \mathrm{mg} / \mathrm{min})$ through an indwelling cannula in the left arm until they were sedated or a maximum of $50-70 \mathrm{mg}$ (depending on body size) had been given. We find that patients requiring more than this cannot be sedated adequately with diazepam alone. ${ }^{8}$ Sedation was judged by a simple clinical test which depends on muscle relaxation. The patient was instructed to keep the right arm flexed at $90^{\circ}$ with the fist firmly clenched while lying supine. Sedation was accompanied by gradual relaxation of the grip, ataxia, and, finally, lowering of the forearm; the latter was taken as the clinical end point. The adequacy of sedation after premedication was noted.

Results of linear regression of diazepam dose, plasma total concentration, and plasma free concentration required for sedation against age

\begin{tabular}{lccccc}
\hline & $\begin{array}{c}\text { No of } \\
\text { patients }\end{array}$ & $\begin{array}{c}\text { Intercept } \\
\end{array}$ & $\begin{array}{c}\text { Slope } \\
(b)\end{array}$ & $\begin{array}{c}\text { Correlation } \\
(r)\end{array}$ & $\mathrm{p}^{*}$ \\
\hline $\begin{array}{l}\text { Diazepam dose }(\mathrm{mg}): \\
\text { All patients }\end{array}$ & 74 & 43.0 & -0.360 & $-0.49 \ddagger$ & $<0.0001$ \\
$\quad$ Subgroup $\dagger$ & 57 & 39.4 & -0.363 & -0.63 & $<0.0001$ \\
Total concentration $(\mu \mathrm{mol} / \mathrm{l}):$ & & & & & \\
$\quad$ All patients & 34 & 13.4 & -0.103 & $-0.52 \S$ & $<0.005$ \\
$\quad \begin{array}{l}\text { Subgroup } \dagger \\
\text { Free concentration }(\mathrm{nmol} / \mathrm{l}):\end{array}$ & 23 & 13.8 & -0.126 & -0.70 & $<0.001$ \\
$\quad$ All patients & 34 & 383 & -2.62 & $-0.42 !$ & $<0.01$ \\
Subgroup $\dagger$ & 23 & 403 & -3.48 & -0.67 & $<0.001$ \\
\hline
\end{tabular}

* Significance of $r$.

patients taking $>40 \mathrm{~g}$ alcohol/day or regular sedation

$\ddagger \S$ Including withdrawals: $\ddagger \mathrm{r}=-0.47(\mathrm{p}<0.0001) ; \S \mathrm{r}=-0.41(\mathrm{p}<0.02) ; 1 \mathrm{r}=$ $0.30(\mathrm{p}<0.075)$.

Conversion: SI to traditional units-Diazepam: $1 \mu \mathrm{mol} / 1 \approx 28.5 \mu \mathrm{g} / 100 \mathrm{ml}$; $1 \mathrm{nmol} / 1 \approx 28.5 \mathrm{ng} / 100 \mathrm{ml}$.

In the second half of the series ( 37 patients) a venous sample was taken from the right arm two minutes after the end of the injection. Plasma was separated and stored at $-20^{\circ} \mathrm{C}$. The plasma total diazepam concentration was measured using a simplified gas-liquid chromatography technique. ${ }^{9}$ The precision of the assay was better than $5 \% .{ }^{910}$ The free diazepam fraction (buffer disintegrations per minute/ corrected plasma disintegrations per minute) was measured by overnight equilibrium dialysis of $0.5 \mathrm{ml}$ unfrozen plasma against $0.5 \mathrm{ml}$ isotonic phosphate buffered saline ( $\mathrm{pH} \mathrm{7.35)}$ containing carbon-14 labelled diazepam $2.5 \mathrm{nmol} / 1(71.3 \mathrm{ng} / 100 \mathrm{ml}){ }^{10}$ Plasma binding was corrected for osmotic changes using the predialysis and postdialysis albumin concentrations, ${ }^{5}$ measured by the bromocresol green method. ${ }^{10}$ Plasma free diazepam concentration was estimated as the plasma total diazepam concentration $\times$ the free diazepam fraction.

The analysis was primarily concerned with the effect of age on diazepam tolerance. ${ }^{10}$ The relation between the dose of diazepam and other variables was first analysed with a multiple regression programme in which the independent variables were inserted one at a time and the overall correlation was determined. ${ }^{11}$ Dummy variables $(0 / 1)$ were used to denote the presence or absence of regular sedation, a high alcohol intake, and smoking and for male or female sex, inpatient or outpatient state, and dental or endoscopic procedure. Regular sedation was defined as taking any form of sedation regularly for one week or more before the procedure and a high alcohol intake as drinking more than $40 \mathrm{~g}$ alcohol a day.

\section{Results}

Four patients who reached the clinical end point were withdrawn because subsequent sedation was unsatisfactory. Three young patients were obviously undersedated and one old patient was oversedated. These patients were included in a second conservative analysis (see table).

Nine patients were receiving regular sedation. Four were receiving daily diazepam $(0 \cdot 5-5 \cdot 0 \mathrm{mg})$, three were receiving nitrazepam $(5 \cdot 0-7.5 \mathrm{mg})$, one lorazepam $(1.0 \mathrm{mg})$, and one trimipramine $(25.0 \mathrm{mg})$.
Nine patients were taking more than $40 \mathrm{~g}$ alcohol a day, and one of these was also receiving regular sedation.

Seven patients required maximum doses of diazepam but were still undersedated. All of these patients were regular users of sedation or large amounts of alcohol.

\section{DOSE OF DIAZEPAM}

Multiple regression analysis showed that a significant proportion $(50 \%)$ of the total variability in the dose required for sedation could be explained by the correlation with age, taking regular sedation, the patient's weight, and taking large amounts of alcohol (fig 1). The dose did not correlate with the plasma albumin concentration or with plasma protein binding. There were no differences in the dose required between men and women, smokers and non-smokers, inpatients and outpatients, or dental and endoscopy patients. Patients with more serious illnesses-for example, malignancy $(n=3)$-tended to require below average doses, but the classification of "illness" was subjective and not included in the multiple regression analysis.

The overall multiple regression equation $(r=0.71 ; p<0.001)$ for the dose required for sedation was: dose in $\mathrm{mg}=29-0.33 \times$ age in years + $0 \cdot 13 \times$ weight in $\mathrm{kg}+18$ (if receiving regular sedation) +12 (if taking more than $40 \mathrm{~g}$ alcohol a day). Thus the predicted dose for a patient aged 50 , weighing $70 \mathrm{~kg}$, and taking little alcohol was $21.6 \mathrm{mg}$ $(29-16 \cdot 5+9 \cdot 1+0+0)$ if not taking sedatives and $39 \cdot 6 \mathrm{mg}(29-16 \cdot 5+$ $9 \cdot 1+18+0)$ if taking a hypnotic regularly.

Figure 1 shows the values for dose of diazepam (mg) plotted against age together with the regression line for the non-sedative and low alcohol intake group. The table gives the corresponding regression equations. Almost all the patients in the regular sedation, high alcohol intake group required more than the average doses required by the non-users. The clinical end point was usually more abrupt in onset and therefore easier to define in the older subjects. This may partly explain the decreased scatter of values about the regression line in those patients.

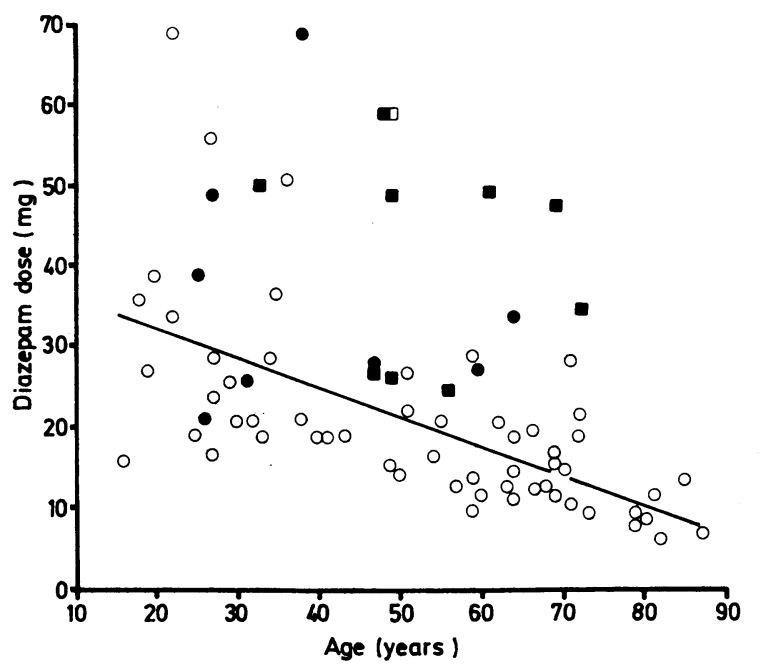

FIG 1 -Doses of diazepam required for sedation $(n=74)$. Patients with high alcohol intake. $\square=$ Patients receiving regular sedation. $\mathbb{D}=$ Patients with high alcohol intake and receiving regular sedation. $\mathrm{O}=$ Regression line for patients with low alcohol intake and no previous sedation $(n=57)$.

\section{PLASMA CONCENTRATIONS}

There was a good correlation between the dose of diazepam and the plasma total $(r=0.83 ; p<0.01)$ and free $(r=0.78 ; p<0.001)$ diazepam concentrations, which was strongest when the dose was corrected for body weight $(\mathrm{mg} / \mathrm{kg})$. Figures 2 and 3 show the values for the plasma concentrations plotted against age. Both the total and free plasma concentrations required for sedation fell twofold to threefold between the ages of 20 and 80 . Patients taking sedatives or large amounts of alcohol regularly tended to require much higher concentrations. The mean free diazepam fraction rose from $2.75 \%$ at age 20 to $3.5 \%$ at age 80 (correlation with age: $r=0.29 ; p<0.075$ ) and was inversely correlated with the albumin concentration $(r=-0.39 ; p<0.01)$. The correlation 
between both the free and total plasma concentrations and age (table) depended on the degree of patient selection. When healthy patients who took little alcohol and no sedatives were selected $(n=18)$ the correlation between plasma free diazepam concentration and age increased from $-0.67(p<0.001)$ to $-0.78(p<0.001)$.

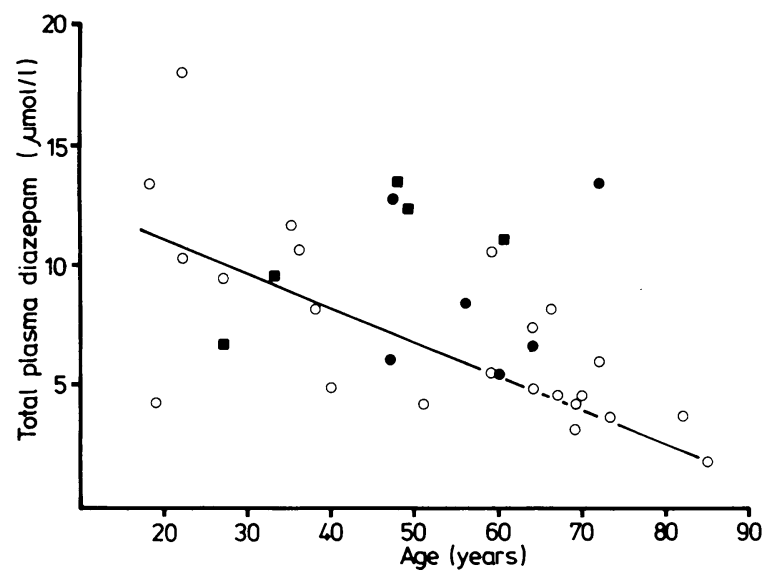

FIG 2-Plasma total diazepam concentrations $(\mathrm{n}=34)$. $=$ Patients with high alcohol intake. $\mathbf{v}=$ Patients receiving regular sedation. $O=$ Regression line for patients with low alcohol intake and no previous sedation $(n=23)$.

Conversion: $S I$ to traditional units-Diazepam: $1 \mu \mathrm{mol} / 1 \approx$ $28.5 \mu \mathrm{g} / 100 \mathrm{ml}$.

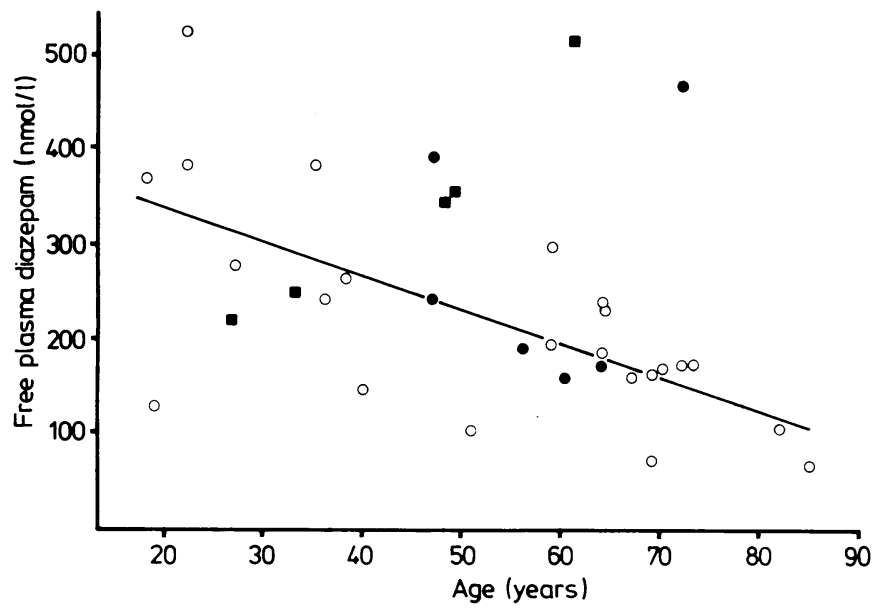

FIG 3-Plasma free diazepam concentrations $(n=34)$. $=$ Patients with high alcohol intake. $=$ Patients receiving regular sedation. $0=$ Regression line for patients with low alcohol intake and no previous sedation $(n=23)$.

Conversion: SI to traditional units-Diazepam: $1 \mu \mathrm{mol} / 1 \approx 28.5 \mu \mathrm{g} / 100 \mathrm{ml}$.

\section{Discussion}

The peak concentration of diazepam after intravenous injection depends on the rate of injection, which should be kept constant in a comparative study. ${ }^{12}$ This makes it difficult to keep the observer "blind" by the use of infusion pumps and so on, since the dose can be estimated from the duration of the injection. We therefore used an "open" study design with a clinical end point which was as unambiguous as possible. The clenched fist sign appeared to give a more reproducible end point than standard signs such as the onset of ptosis or failure to answer questions. In four subjects who required follow up endoscopies after more than three months the dose required varied by less than $20 \%$. The degree of sedation was greater than usually required for minor procedures but the sign is recommended for premedicating difficult patients such as the very anxious or those who show a high degree of tolerance. In these patients minor procedures may end in distressing failure and there is a risk of injury unless sedation is adequate.

The doses required to produce the same degree of sedation varied between 8 and $70 \mathrm{mg}$, and even the highest doses were not enough for many patients. The results emphasise the importance of titrating the dose against a clinical end point rather than administering a fixed dose. The regression of dose and total plasma concentration against age agreed well with the results of other studies. ${ }^{12}$ Our study confirms that sensitivity to diazepam increases twofold to threefold with aging but that patients taking benzodiazepines regularly, even those taking low doses, or regular alcohol usually show pronounced tolerance to the drug. Some patients were hardly affected after receiving $50 \mathrm{mg}$ diazepam. A slow injection of $10-50 \mathrm{mg}$ pethidine given after taking the blood sample invariably produced adequate sedation in these patients.

The increase in free drug concentration that occurs with aging is unlikely to account for the change in clinical response. The dose of diazepam did not correlate with the degree of plasma protein binding. Diazepam enters the brain extremely rapidly after intravenous injection ${ }^{13}$ and is probably almost completely cleared from plasma during a single passage. ${ }^{10}$ Under these conditions a decrease in plasma binding will tend to decrease rather than increase cerebral uptake because it will reduce the rate at which diazepam is delivered to the brain. ${ }^{14}$ The differences in clinical tolerance can be explained only by changes in the central nervous system response (pharmacodynamic tolerance).

The cause of the altered neurological response is unknown. Specific benzodiazepine receptors have been identified within the central nervous system ${ }^{15}$ but studies in rats-which also show age related changes in benzodiazepine sensitivity ${ }^{1016}$-have failed to detect any change in the number or affinity of benzodiazepine receptors. ${ }^{1017-19}$ These observations suggest that the change in response is due to changes in the postreceptor mechanism of action.

We thank Dr Stuart Pocock and Ms D Ashby, of the clinical epidemiology department, Royal Free Hospital, for their help and advice during the statistical analysis.

\section{References}

Reidenberg MM, Levy $M$, Warner $\mathrm{H}$, et al. Relationship between diazepam dose, plasma level, age and CNS depression. Clin Pharmacol Ther 1978;23:371-4. Giles HG, Macheod SM, Wright JR, Sellers EM. Influence of age and previous use on diazepam dosage required for endoscopy. Can Med Assoc $\mathcal{F}$ 1978;118: 513-4

${ }^{3}$ Boston Collaborative Drug Surveillance Program. Clinical depression of the central nervous system due to diazepam and chlordiazepoxide in relation to

+ Jaffe JH. Drug addiction and drug abuse. In: Goodman LS, Gilman A, eds. The Pharmacological basis of therapeutics. 6th ed. New York: Macmillan, 1980:552. bel JG, Sellers EM, Naranjo CA, Shaw J, Kadar D, Romach MK. Inter- and intrasubject variation in diazepam free fraction. Clin Pharmacol Ther $1979 ; 26$ :
$247-55$.

Greenblatt DJ, Allen MD, Harmatz JS, Shader RI. Diazepam disposition determinants. Clin Pharmacol Ther 1980;27:301-11.

Macklon AF, Barton $M$, James $O$, Rawling $M D$. The effect of age on the pharma-

cokinetics of diazepam. Clin Sci 1980;59:479-83. copy. A trial of atropine, pentazocine or pethidine as a supplement to diazepam. Scand $\mathcal{f}$ Gastroenterol 1978;13:33-9.

"Rutherford DM. Rapid micromethod for the measurement of diazepam and desmethyldiazepam in blood plasma by gas-liquid chromatography. $\mathcal{F}$ Chromatogr 1977;137:439-48.

"Cook PJ. Diazepam pharmacodynamics and ageing. Bristol: Bristol University, 1983. (MD thesis.)

' Nie NH, Hull CH, Jenkins JG, Steinbrenner K, Brent DH. Statistical package for the social sciences. 2nd ed. New York: McGraw-Hill, 1975

Korttila K, Mattila MJ, Linnoila $M$. Prolonged recovery after diazepam sedation: the influence of food, charcoal ingestion and injection rate on the effects of intravenous diazepam. Br $\mathcal{F}$ Anaesth 1976;48:333-9.

arattini S, Mussini E, Marcucci F, Guatani A. Metabolic studies on benzo: Garattini S, Mussini E, Randall IO, eds. The benzodiazepines. New York: Raven Press, 1973:75-97.

is Sjoqvist F, Borga O, Orme M L'E. Fundamentals of clinical pharmacology. In Avery GS, ed. Edinburgh: Churchill Livingstone, 1980:18.

15 Tallman JF, Paul SM, Skolnick P, Gallagher DW. Receptors for the age of anxiety: pharmacology of the benzodiazepines. Science $1980 ; 207: 274-81$.

${ }^{16} \mathrm{Komiskey} \mathrm{HL}$, Cook TM, Lin CF, Hayton WL. Impairment of learning or memory in the mature and old rat by diazepam. Psychopharmacology (Berlin) $1981 ; 73: 304-5$.

17 Pedigo NW, Shoemaker $\mathrm{H}$, Morelli $\mathrm{M}$, et al. Benzodiazepine receptor binding in young, mature and senescent rat brain and kidney. Neurobiol Aging 1981;2:83-8 Tsang CC, Speed KV, Wilkinson GR. Ageing and benzodiazepine binding in the rat cerebral cortex. Life Sci $1982 ; 30: 343-6$

cook PJ, James IM. Changes in benzodiazepine receptor binding with ageing in

Accepted 17 May 1984) 